\title{
RESPONSES TO THE SHORT-TERM EFFECT OF THE ZERO PER CENT FEE INCREASE ON SOUTH AFRICAN UNIVERSITIES
}

\author{
A. Moolman* \\ e-mail: anneke.moolman@nwu.ac.za
}

\section{Jacobs*}

e-mail: 12690988@nwu.ac.za

*School of Accounting Sciences

North-West University

Vanderbijlpark, South Africa

\section{ABSTRACT}

In a response to a wave of \#FeesMustFall student protests, South Africa's presidency announced that there would be no student fee increases in the country's public higher education in 2016, which resulted in sudden shortfalls at universities. In addition, universities are faced with sturdy growth objectives set forth by the government combined with the reality of ever tightening budgets. We therefore performed a preliminary, qualitative study to explore the immediate responses of universities following the announcement. Our findings indicate that although the government contributed to the shortfall, some universities had to account for up to 30 per cent of it themselves. This resulted in relocation of funds, challenging the institutions' ability to meet the range of requirements set. Universities reported their concern about future planning in the context of lower student fees for 2016 and beyond in the absence of information regarding future funding. On the hand of Lewin's change management model, we find that the change process was insufficiently supported by the government and the Department of Higher Education and Training, leaving it incomplete. The present study provides a starting point for determining the ability of universities to meet growing requirements from the government, within existing and potentially worsening financial constraints, in further detail.

Keywords: \#FeesMustFall, \#FeesHaveFallen, Department of Higher Education and Training, DHET, South Africa, higher education, budget constraints

\section{INTRODUCTION}

On 23 October 2015, six weeks before university staff take their summer break, an unexpected news report informed public higher education institutions that there would be no tuition fee increase for the 2016 academic year after an announcement to that effect by President Jacob Zuma (Allison 2015). Most universities’ 2016 financial planning had been finalised by April 2015 and, in November 2015, the Department of Higher Education and Training (DHET) 
informed these institutions about the government's plans to address the shortfall: anything between 70 and 100 per cent of the direct shortfall would be covered by the state. This gave universities no more than a month to re-plan their budgets before the start of the new academic year in January 2016.

Given the unprecedented sudden shortfall in many university budgets, even as the institutions had to continue to fulfil stipulated requirements for growth and research outputs set by the DHET, this study sought to explore the initial responses from the finance units of South African universities as to how they experienced the first three months of the new academic year in these crisis conditions. They were asked to report on their reactions to the shortfall by answering a set of questions connected with the immediate effects of the zero fee increase. This preliminary, qualitative, exploratory study therefore allowed institutions to express their views and reactions. Further information was gathered from the general media and formal government documents.

\section{THE ROLE OF UNIVERSITIES IN THE SOUTH AFRICAN CONTEXT}

The role of universities as part of the community is undisputed: training, research and community engagement (DHET 2013, 38-39). Apart from the fact that quality education contributes to a person's health, sustainability, quality of life, self-esteem, and ability to actively engage and be empowered (DHET 2013; National Planning Commission 2011), higher education directly addresses the needs of a country's economy and promotes growth (DHET 2013, 2). It contributes to increased incomes and productivity, enables the move towards a knowledge-intensive economy, and plays a crucial role in helping to reduce the high unemployment rate (National Planning Commission 2011, 38). The DHET (2013) and the National Planning Commission (2011) both perceive the expansion of higher education as vital to South Africa's economy. Therefore, there is a growth instruction and expectation from the government: the insistence and fast tracking of education to students who come from a variety of schools, many of whose learners have had difficulty preparing for university.

Currently, South African universities display relatively low year on year throughput rates (74\% compared to the desired norm of $80 \%$ ), which results in low three-year degree graduation rates in contact education (15\% compared to the international norm of 25\%) (DHET 2013, 3132). The reasons for poor performance by universities include (DHET 2013, 32):

- $\quad$ entrants from poor school education backgrounds, increasing the cost to produce graduates (also supported by National Planning Commission (2011, 40));

- $\quad$ entrants who are usually not well-prepared for university, which is further complicated by 
high student-to-staff ratios;

- $\quad$ lacking support systems for students;

- $\quad$ inadequate student funding, resulting in poor living and studying conditions; and

- $\quad$ professional development and recognition of undergraduate academic staff fall short.

It is in these circumstances that events occurred that have never happened in South Africa's higher education before (Omar 2016). It took only ten days of revolutionary student protest for South African students to accomplish the demand of zero per cent fee increases in 2016 university fees (Fataar 2015). Protests started on 14 October 2015 at Wits University in Johannesburg after an announcement of a 10.5 per cent increase (Fataar 2015), almost double the current rate of inflation, was aired (Fourie 2015). \#FeesHaveFallen, leading to a R2.33 billion shortfall for South African universities (Bernardo 2015).

\section{FUNDING OF UNIVERSITIES}

There are three main sources of income for public universities, namely: the government, student fees and private sources (News24Wire 2015). In terms of the Estimates of National Expenditure, the government aims to promote an effective and efficient university education system, and to support universities, the National Student Financial Aid Scheme (NSFAS) and national institutes for higher education financially (National Treasury 2016, 247).

Higher education is expensive and although most universities receive third-stream income, all universities are dependent on student fees. Tuition fees have risen substantially to meet the growth requirements set forth by the government: an average fee increase of nine per cent was implemented over the past four years, in comparison with the country's inflation rate for the same period of five per cent (DHET 2013, 37). The increasing tuition fees have acted as a barrier of entry to many students (DHET 2013, 37), causing many to lose the opportunity of tertiary qualifications, and thereby also a higher quality of life due to enhanced employability and possible increased salaries (Statistics South Africa 2015). Unsustainable fee increases may result in a reduction in the number of year-on-year university enrolments (DHET 2013, 37), leading to job losses in the tertiary education sector as well, and ultimately hindering economic growth. The DHET therefore stated in 2013 that the government would consider ways of controlling fee increases (DHET 2013, 37)

However, the government funding has not kept up with the financial requirements of the system. Over the last ten years a decrease of nine per cent in the government subsidies as a part of total university income was shown, while student fees only increased by seven per cent 
(News24Wire 2015). Even though student numbers have increased by 69.8 per cent between 2000/01 and 2014/15, total nominal state finances for universities as a proportion of gross domestic product increased by only 25.4 per cent, and total state finance for universities as a proportion of total state expenditure decreased by 9.8 per cent for the same period (Institute of Race Relations 2016). The year on year decrease in government funding per student headcount explains why universities were obliged to raise tuition fees at higher than inflation rates (see Figure 1).

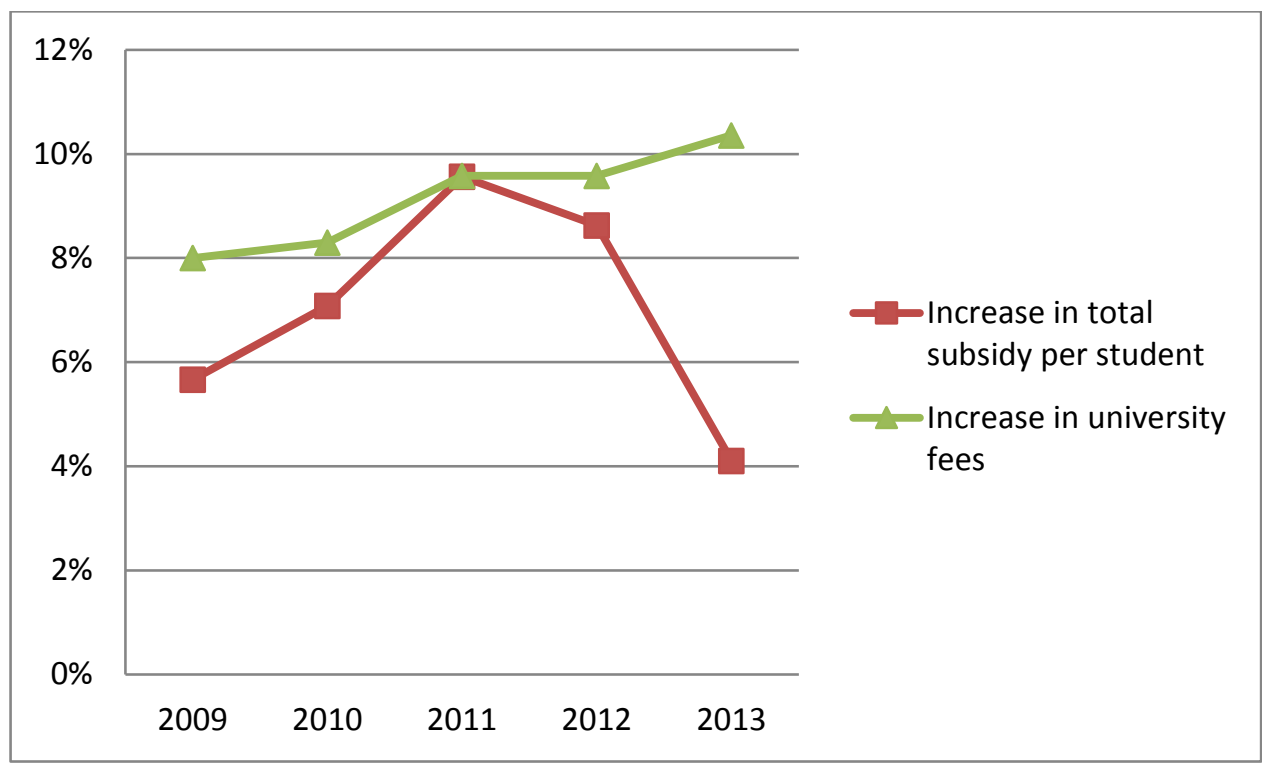

Figure 1: Displaying the growth in total government funding per student in relation to the increase in university fees from 2009 to 2013

Sources: Own calculation based on various secondary sources (DHET 2015; Centre for Higher Education Transformation 2015; DHET 2016; Fin24 2015).

The division of the government's budget between grant categories has also changed significantly over the past ten years. Earmarked grants used to constitute eight per cent of funding provided to universities in 2004/05, but currently constitute 32 per cent of funding (Table 1). Earmarked grants are awarded towards specific objectives, which therefore leave universities with less flexibility on how to apply the funds.

Table 1: The government's budget allocation between grant categories to universities

\begin{tabular}{|l|l|l|}
\hline & $\begin{array}{l}\mathbf{2 0 0 4 / 0 5} \\
(\mathrm{DHET} 2004,5)\end{array}$ & $\begin{array}{l}\mathbf{2 0 1 5 / 1 6} \\
(\mathrm{DHET} 2014,3)\end{array}$ \\
\hline Institutional restructuring & 3 & - \\
\hline Earmarked grants & 8 & 32 \\
\hline Block grants & 87 & 68 \\
\hline Total & 100 & $\mathbf{1 0 0}$ \\
\hline
\end{tabular}


Universities are faced with decreased funding in real terms from the government, forcing the institutions to higher increases in tuition fees. Increased funding is required by universities to maintain and grow student numbers and quality in higher education and research, as is required by the DHET.

\section{THE GOVERNMENT'S REQUIREMENTS FOR UNIVERSITIES}

The New Growth Plan (Economic Development Department 2011, 30) intends to develop South Africa into 'the higher education hub for the continent'. South African universities therefore have certain goals to achieve (Wangenge-Ouma and Cloete 2008, 906), which are stipulated in the National Plan for Higher Education as (Department of Education 2001):

- $\quad$ producing the graduates needed for social and economic development in South Africa;

- $\quad$ achieving equity in the South African higher education system;

- $\quad$ achieving diversity in the South African higher education system;

- $\quad$ sustaining and promoting research; and

- $\quad$ restructuring the institutional landscape of the higher education system.

Further objectives of the government include progressing towards free education for the poor at South African universities (DHET 2013, xiv) and to eliminate patterns that exclude the majority (National Planning Commission 2011, 17), which the zero per cent fee increase announcement addresses somewhat. The planned actions of the National Development Plan (National Planning Commission 2011, 61) included providing all students who qualify for the NSFAS with access to full funding. Also, students not qualifying for the NSFAS should have access to commercial loans, backed by state securities.

The objectives of the government include the increase of enrolment at universities from 950000 to about 1.62 million, increasing the doctoral qualified staff in higher education from 34 per cent to 75 per cent, delivering at least 5000 annual doctoral graduates by 2030, up from 1420 in 2010, and to increase science, technology and innovation outputs (National Planning Commission 2011, 59). Up to February 2016, about five years into the 20 years of the government's development plan, universities have increased enrolments to 1.001 million students, and annual doctoral graduates to 2060 (National Treasury 2016, 237). This indicates that universities still have much to achieve in the 15 years to come.

The government has stressed that staffing of universities needs to be addressed by recruiting and retaining academics in an attractive academic career, while improving their 
qualifications and service conditions (DHET 2013, xiv). Academics are faced with doing more and more with less and less as resource constraints and pressure to bring in outside funding increases (DHET 2013, 36).

The government ultimately requires an improvement in quality education and innovation through research from South African universities (National Planning Commission 2011; DHET 2013; Wangenge-Ouma and Cloete 2008). However, achieving these objectives will require universities to significantly expand their infrastructure, establish effective administrative systems, and recruit, train and retain high quality higher education staff; all these will require significant funding (DHET 2013, 29-30). The non-achievement of the goals set forth by the government is therefore under pressure due to financial constraints (Wangenge-Ouma and Cloete 2008; DHET 2013) like the zero per cent fee increase crisis.

\section{CHANGE MANAGEMENT}

The unexpected zero fee increase announcement brought forth changes to South African universities. Change management therefore became crucial to ensure the on-going success of these institutions. Lewin's change management model is considered as the most powerful and fundamental model to enable successful change (Levasseur 2001, 73). It provides essential guidance for change through a three-stage process and can be implemented during a situation such as \#FeesMustFall. The three stages of this model are:

- unfreeze;

- change; and

- $\quad$ refreeze.

In the unfreeze stage, it needs to be determined how the status quo is preventing the organisation, ensuring a need for change (Levasseur 2001, 73). Schein (1996, 1-3) emphasised that the problem with change is that counterforces are experienced, forcing the situation back to equilibrium, which necessitates the unfreeze stage. It is therefore vital that the current truth should be disconfirmed, to such an extent that it increases motivation to change. This often creates an anxiety of losing self-confidence, as change is necessary to replace or enhance existing conditions, which used to be the norm. Consequently, an environment of psychological safety is important, encouraging and enabling change. Levasseur (2001, 73) highlights the significance of communication as part of the necessary support, so that all role players are aware of the reason and benefits surrounding the change. 
During the change phase, a fresh perspective is encouraged to move the target circumstances to a new equilibrium (Kritsonis 2005, 2). Leadership should actively engage the participants through communication, education and support (Levasseur 2001, 73).

Once the refreeze stage is entered into, ways need to be developed to sustain the change and support and training are of utmost importance (Levasseur 2001, 73). Supervision may aid in this process, otherwise role players may revert to prior actions (Schein 1996, 7). The refreezing process involves integrating the new values into the existing traditions (Kritsonis 2005, 2).

\section{RESEARCH DESIGN AND INSTRUMENT}

Open-ended questionnaires were sent to the finance departments of the 26 public South African universities, of which eight were returned, for non-sensitive information about how they were responding to the situation and to what extent it may affect future planning. The questionnaire was structured to elicit responses based on the day-to-day practical handling of financial dilemmas the financial units face as they were dealing with the crisis. The idiosyncratic data collected was interpreted and sorted into relevant categories. The questionnaires were supplemented by press releases and information obtained from universities' websites as secondary data.

\section{RESULTS}

\section{Results from the open-ended questionnaire}

The aggregated responses collected from the different South African universities' finance departments on the short-term effect of the zero per cent fee increase announcement are presented in Table 2. Feedback is divided into feedback received from universities that received 100 per cent of the shortfall from the government and universities that did not receive the full shortfall.

Table 2: Feedback received from universities regarding the short-term effect of the zero per cent fee increase announcement

\begin{tabular}{|c|c|c|}
\hline Categorised Questions & $\begin{array}{l}\text { Responses by universities that } \\
\text { received } 100 \% \text { of the shortfall } \\
\text { from the government }\end{array}$ & $\begin{array}{l}\text { Responses by universities that received } \\
\text { approximately } 75 \% \text { of the shortfall from } \\
\text { the government }\end{array}$ \\
\hline \multicolumn{3}{|c|}{ A) Planning \& Communication } \\
\hline $\begin{array}{l}\text { Was the zero per cent fee } \\
\text { increase expected by the } \\
\text { university? If so, how did the } \\
\text { university plan to minimise the } \\
\text { effect thereof? }\end{array}$ & $\begin{array}{l}\text { None of the universities expected } \\
\text { a zero per cent fee increase. Most } \\
\text { of the universities' budgets were } \\
\text { already finalised and therefore no } \\
\text { plan was in place. }\end{array}$ & $\begin{array}{l}\text { None of the universities expected a zero per } \\
\text { cent fee increase. Most of the universities' } \\
\text { budgets were already finalised and therefore } \\
\text { no plan was in place. }\end{array}$ \\
\hline
\end{tabular}




\begin{tabular}{|c|c|c|}
\hline Categorised Questions & $\begin{array}{l}\text { Responses by universities that } \\
\text { received } 100 \% \text { of the shortfall } \\
\text { from the government }\end{array}$ & $\begin{array}{l}\text { Responses by universities that received } \\
\text { approximately } 75 \% \text { of the shortfall from } \\
\text { the government }\end{array}$ \\
\hline $\begin{array}{l}\text { What official communication } \\
\text { has been received from the } \\
\text { government? }\end{array}$ & $\begin{array}{l}\text { Universities received } \\
\text { communication to advise that } \\
100 \% \text { will be compensated for the } \\
\text { shortfall of income. }\end{array}$ & $\begin{array}{l}\text { Universities received communication on the } \\
\text { contribution from the DHET for the shortfall in } \\
\text { fees between late November } 2015 \text { and early } \\
\text { January } 2016 \text {. }\end{array}$ \\
\hline $\begin{array}{l}\text { How does the university plan to } \\
\text { attend to similar circumstances } \\
\text { in future? }\end{array}$ & $\begin{array}{l}\text { Implement strategies with the aim } \\
\text { to increase third stream income } \\
\text { and to reduce expenditure within } \\
\text { the universities. }\end{array}$ & $\begin{array}{l}\text { Most institutions are heavily reliant on tuition } \\
\text { fees and some would close down within two } \\
\text { to three months with the lack thereof. Most } \\
\text { funding from outside agencies is however } \\
\text { strictly, and understandably, ring-fenced for } \\
\text { particular purposes. Universities are } \\
\text { therefore forced to implement strategies with } \\
\text { the aim to increase third stream income and } \\
\text { to reduce expenditure within the universities. }\end{array}$ \\
\hline \multicolumn{3}{|c|}{ B) Finances } \\
\hline $\begin{array}{l}\text { How did the zero per cent fee } \\
\text { increase affect the university's } \\
\text { budget? What was the bottom- } \\
\text { line effect of the shortfall } \\
\text { between the original budget and } \\
\text { what actually occurred? }\end{array}$ & $\begin{array}{l}\text { No effect, as the government } \\
\text { refunded the full shortfall. }\end{array}$ & $\begin{array}{l}\text { The announcement led to an immediate } \\
\text { shortfall of between R45 million and R180 } \\
\text { million per university, depending on the } \\
\text { tuition fee structure of the universities. } \\
\text { Indirect effects of the announcement } \\
\text { included: } \\
\text { - Immediate increases in outstanding } \\
\text { student debt, as students were awaiting } \\
\text { further announcements regarding free } \\
\text { higher education. } \\
\text { - Operational and capital expenditure } \\
\text { reconsideration due to lack of funds, which } \\
\text { in turn may influence universities' growth, } \\
\text { strategy and/or quality. } \\
\text { - Higher education may have lost its status } \\
\text { as a privilege and something to aspire to. }\end{array}$ \\
\hline $\begin{array}{l}\text { What percentage of the shortfall } \\
\text { has been covered by the } \\
\text { government? Has it already } \\
\text { been paid? If not, when is it } \\
\text { expected? }\end{array}$ & $\begin{array}{l}100 \% \text { of the shortfall is covered by } \\
\text { the government: } 50 \% \text { was paid in } \\
\text { January and the remaining } 50 \% \\
\text { between April and May } 2016 \text {; or } \\
100 \% \text { was paid in January } 2016 \text {. }\end{array}$ & $\begin{array}{l}\text { Between } 70 \% \text { and } 84 \% \text { of the shortfall is } \\
\text { covered by the government. } 50 \% \text { of the } \\
\text { amount covered by the government was } \\
\text { received in January } 2016 \text {, and the remaining } \\
50 \% \text { will be received during April } 2016 \text {. }\end{array}$ \\
\hline $\begin{array}{l}\text { Have alternative sources of } \\
\text { income been discovered/ } \\
\text { increased (e.g. international } \\
\text { funding/thirds income streams)? }\end{array}$ & $\begin{array}{l}\text { Not applicable as the government } \\
\text { refunded } 100 \% \text { of the shortfall. }\end{array}$ & $\begin{array}{l}\text { Universities are in the process of } \\
\text { investigating additional/alternative income } \\
\text { streams and strategies were introduced to try } \\
\text { to optimise third stream subsidies and } \\
\text { funding opportunities. }\end{array}$ \\
\hline $\begin{array}{l}\text { Has the government decreased } \\
\text { its subsidy to the university in } \\
\text { prior years? }\end{array}$ & $\begin{array}{l}\text { Most of the universities are in } \\
\text { agreement that there was no } \\
\text { decrease in subsidies during the } \\
\text { previous years except for the } \\
\text { university where the government } \\
\text { decreased the distributable } \\
\text { portion of subsidies in prior years } \\
\text { and increased the earmarked } \\
\text { portion of subsidies. }\end{array}$ & $\begin{array}{l}\text { Most universities are in agreement that, } \\
\text { although subsidies received from the } \\
\text { government have increased in nominal } \\
\text { terms, they have decreased in real terms. } \\
\text { Subsidy increases are not linked to CPI } \\
\text { factors even though the universities are } \\
\text { prone to the same cost increases as normal } \\
\text { businesses. Also, the sector has significantly } \\
\text { grown in student numbers over the last two } \\
\text { decades, affecting the distribution of } \\
\text { subsidies. }\end{array}$ \\
\hline $\begin{array}{l}\text { Where did the university decide } \\
\text { to cut costs? Will these costs be } \\
\text { recoverable in future? }\end{array}$ & $\begin{array}{l}\text { No need to cut costs as } \\
\text { government refunded } 100 \% \text { of the } \\
\text { shortfall. }\end{array}$ & $\begin{array}{l}\text { Main cost cutting occurred on operational } \\
\text { expenditure and staff, with a minimum } \\
\text { increase on salaries; additional non- } \\
\text { academic positions were frozen. Transport } \\
\text { costs, bursaries and scholarships for } \\
\text { students were decreased. }\end{array}$ \\
\hline $\begin{array}{l}\text { How much of the tuition fees } \\
\text { received from students are paid } \\
\text { back to students in the form of } \\
\text { bursaries? Were the fees } \\
\text { allocated to bursaries reduced } \\
\text { as a result of the shortfall? }\end{array}$ & $\begin{array}{l}\text { For some of the universities there } \\
\text { was no change in the percentage } \\
\text { of bursaries paid back to the } \\
\text { students as these universities had } \\
\text { no shortfall. }\end{array}$ & $\begin{array}{l}\text { Universities give internal bursaries of up to } \\
14 \% \text { of the universities' total fees and levies. } \\
\text { Some universities had to reduce the internal } \\
\text { bursaries and scholarships by } 60 \% \text { due to } \\
\text { the announcement of no fee increase. }\end{array}$ \\
\hline \multicolumn{3}{|c|}{ C) Potential future effects } \\
\hline Does the cost cutting result in a & Not applicable as the government & Universities placed their focus to ensure that \\
\hline
\end{tabular}




\begin{tabular}{|l|l|l|}
\hline Categorised Questions & $\begin{array}{l}\text { Responses by universities that } \\
\text { received 100\% of the shortfall } \\
\text { from the government }\end{array}$ & $\begin{array}{l}\text { Responses by universities that received } \\
\text { approximately 75\% of the shortfall from } \\
\text { the government }\end{array}$ \\
\hline $\begin{array}{l}\text { decrease in the quality of } \\
\text { education, research or } \\
\text { community work? }\end{array}$ & $\begin{array}{l}\text { cost cutting will not influence the core } \\
\text { function of the universities (education), } \\
\text { although some are of the opinion that this is } \\
\text { inevitable. Growth opportunities, the ability to } \\
\text { expand and the impact on research outputs } \\
\text { will definitely be influenced. This is due to } \\
\text { much needed expansion in infrastructure and } \\
\text { capital equipment in the education and } \\
\text { research sector that is prohibited. }\end{array}$ \\
\hline $\begin{array}{l}\text { Does the university expect that } \\
\text { the government would regulate } \\
\text { tuition fees from now on? }\end{array}$ & $\begin{array}{l}\text { One of the universities feels that } \\
\text { the regulation of fees would } \\
\text { undermine the councils of } \\
\text { universities. Universities feel that } \\
\text { there is a strong possibility that } \\
\text { the government will regulate } \\
\text { tuition fees going forward in light } \\
\text { of the 'fees must fall' campaign. }\end{array}$ & $\begin{array}{l}\text { A strong possibility exists that the } \\
\text { government would like to regulate tuition fees } \\
\text { going forward. This can be seen as a threat } \\
\text { for the higher education sector in South } \\
\text { Africa. Moving this pressure to taxpayers, } \\
\text { would subject universities to unwarranted } \\
\text { scrutiny. }\end{array}$ \\
\hline $\begin{array}{l}\text { Does the university plan a } \\
\text { higher increase in 2017 to cover } \\
\text { the 2016 shortfall? }\end{array}$ & $\begin{array}{l}\text { Not applicable as the government } \\
\text { refunded 100\% of the shortfall. }\end{array}$ & $\begin{array}{l}\text { None of the universities plan to increase } \\
\text { tuition fees based on the shortfall from } 2016, \\
\text { but they hope that the government would } \\
\text { include the shortfall in the baseline of } \\
\text { institutions' subsidy allocations. }\end{array}$ \\
\hline
\end{tabular}

\section{RESULTS FROM SECONDARY DATA}

A total of R396.1 million of the shortfall (17\% of the R2.33 billion) due to the zero per cent fee increase needed to be covered by universities (DHET 2016). According to Blade Nzimande, Minister of Higher Education and Training, wealthier universities, such as the University of Cape Town (UCT) and the University of the Witwatersrand (Wits), proposed to carry the deficit for the first four months of 2016 (Bernardo 2015).

Apart from the direct shortfall that the announcement had on universities of up to R200 million (Rensburg 2016), Venter (2015) reported that continuous strikes, along with related media coverage, reflect poorly on South Africa as they are generally accompanied by violence and chaos. The damage to university infrastructure due to violent protests regarding higher education fees amounted to approximately R460 million as at 9 June 2016 (News101 2016). This contributes to reducing foreign investment in the country, as indicated by the rand that fell more than four per cent against the dollar within the period 19 to 28 October 2015 (Wild and Mbatha 2015).

Universities were, however, full of empathy for the motivation for the zero per cent fee increase strike by students, yet also extremely worried about the financial outcome of the zero per cent fee increase:

We support the announcement by President Zuma, after consultation with university leaders. This will provide enormous relief for struggling students and their families across the three campuses. We now look forward to the details of how universities will be supported financially to enable this to happen (Jansen 2015). 
I must emphasise that Unisa has a deep understanding for the issues raised by the students nationwide. By now we were hoping to have had more clarity on the way in which the zero per cent fee increase would be supported by the government (Makhanya 2015).

Universities are supportive and are empathetic towards the plight of students who cannot afford higher education. Although universities receive a high portion of NSFAS funding, there is still an annual shortfall to assist all qualifying students, prompting universities to tighten its belt to help deserving students (Van Staden 2015).

Fourie (2015) was of the opinion that the problem of high tertiary education fees could be resolved through one of three ways:

- $\quad$ Cutting the budget. However, this normally means discontinuing new infrastructure or maintenance on existing infrastructure, which is already a problem as facilities have not kept up with growing student numbers.

- Third stream income. Although this would be an option, third stream funding is normally contingent, and would also not be possible with deteriorating infrastructure.

- Increased transfers from the government. This seems to be the only alternative, although South Africa already lags behind other countries and contributions per student have consistently fallen over the past few years.

\section{DISCUSSION}

A need for change to accommodate free education for the poor was already identified by the DHET in 2013 (DHET 2013, xiv), and encouraged through the higher education institution objectives set forth by the DHET. Although change was in process, the immediate need to change the existing status quo was once again highlighted by the student protests during the \#FeesMustFall campaign, highlighting the fact that a new funding system is required. As the traditional funding model was disconfirmed, role players, such as the government, the DHET and universities, were motivated to fasten the change process. Communication was encouraged during this process of unfreezing, as shortly after the announcement of the zero per cent fee increase, the DHET requested universities to submit an outline of the financial effect of implementing the zero per cent fee increase, where after a letter was received from the DHET regarding the subsidy allocated for the shortfall in fees. Universities that received 100 per cent of the immediate shortfall were mostly historically disadvantaged institutions that would not have been able to carry any deficit.

Although universities received communication from the DHET of the subsidy that will be received during the change process, support from the government was limited. University leadership was therefore obliged to offer the necessary support to their personnel in reshuffling 
existing budgets to ensure the continuation of higher education activities. Because of the sudden nature of the announcement, universities were not prepared to create additional third stream income to compensate for the shortfall, which caused severe cash flow constraints, halting possibilities of expansion in terms of infrastructure and initiatives that needed to be scaled down or cancelled. This decrease of infrastructure expansion may lead to decreasing enrolments at universities. Institutions cut down on areas such as furniture and computer equipment, staff costs, bursaries and scholarships to students and student transport costs. Universities used to give internal bursaries of up to 14 per cent on tuition fees and some universities were planning on expanding new scholarship funds, although this needed to be cut down by up to 60 per cent due to the shortfall. Universities were also forced to scrutinise budgets for other opportunities to lower variable and fixed costs and to emphasise cost control. The ultimate effect was therefore that universities that received less than 100 per cent of the shortfall were forced to cut down on capital, operational and student support expenditure. The reduction of funding in these areas hinders growth in under- and postgraduate students and attraction and development of quality higher education staff. As the core function of universities is education, research outputs will be impacted adversely.

For all universities, including universities that received 100 per cent of the shortfall from the government, the zero per cent fee increase will have a knock on effect for future years and is therefore a permanent loss. In order to reduce this, universities are investigating prospects to optimise subsidies and funding opportunities and to expand third stream income. Universities do not expect to increase tuition fees at a higher than normal rate in 2017 as this would be unsustainable.

Universities' strategies and financial planning are currently under pressure. The 2016 shortfall is considered to be a permanent loss and if the DHET continues to regulate university fees and only allow universities to, for example, increase university fees by CPI, they will have detrimental losses, and growth could seriously be inhibited. This may result in the nonachievement of the objectives set by the DHET. An expectation has been created that the government will intervene in tuition increases in future, and therefore if a new, feasable funding model is not implemented financial viability of South Africa's higher education is threatened and the quality of education will be impacted.

The government's ability to regulate tuition fees would, however, be limited by their availability of funds. Should the financial pressure be placed on taxpayers' pockets, universities would also be subject to increased investigation.

Further intervention for the 2017 fee increases was experienced as Minister Nzimande announced an eight per cent increase in university fees for students whose family earns more 
than R600 000 per annum, and therefore approximately 70 per cent of students will still pay 2015 tuition rates in 2017 (Bateman and Bendile 2016).

Due to the uncertainty regarding funding in the higher education sector, the refreeze stage of change has not been entered into. Refreezing will only be a possibility once a sustainable funding framework is put forth by the presidential commission in 2017 (Bateman and Bendile 2016).

\section{CONCLUSION}

Objectives towards the country's higher education institutions' growth through the improvement of quality education and innovation have been set forth in documents such as the New Growth Path, the National Development Plan 2030, the National Plan for Higher Education and the White Paper for Post-School Education and Training. Although enrolment at universities has to increase by a further 62 per cent, governmental funding has not kept on par with such stipulations. Universities are therefore expected to meet the objectives set forth by the DHET, but within tightening budgets. This was traditionally done by fee increases above the inflation rate.

It is in these circumstances that a zero per cent tuition fee increase announcement was made that resulted in a deficit of R2.33 billion to the 26 South African universities, of which the government covered between 70 and 100 per cent. To manage the deficit, universities cut down on capital and operational expenditure, including infrastructure, furniture and computer equipment, staff costs, bursaries and scholarships, and student transportation costs. This threatens growth in student numbers (and therefore graduates), the ability of universities to attract and retain quality staff and possibilities of scientific, technological and innovative breakthroughs as required by the DHET. Ultimately, shortfalls to higher education institutions intimidates economic growth of the country.

The protest-related occurrences have, however, introduced opportunities to design strategies to address the problem of expensive higher education. Students' zero per cent increase victory will never the less be short-lived without a feasible strategy for addressing the shortfall, which would force universities once again to increase tuition fees.

Although the process of change has commenced, this study finds that insufficient support was provided to universities during the change stage of Lewin's change management model. Due to the uncertainty surrounding future funding that higher education institutions face, the refreeze stage has not yet been entered into, emphasising that change surrounding the \#FeesMustFall campaign has not been concluded.

Whereas this study focused on the immediate reactions of universities in light of the 
sudden fee reduction, further research could investigate whether these reactions sufficiently managed the crisis and how it affected future planning in the higher education sector of South Africa. Further research could also determine South African universities' abilities to deliver on the objectives set forth by the DHET within the budgetary limitations. This study determined that it is difficult to achieve the growing requirements from the government with insufficient funding that will lead to potentially worsening financial constraints. These limitations do, however, create opportunities for universities to develop strategies in terms of third stream income.

\section{REFERENCES}

Allison, S. 2015. \#FeesHaveFallen: A big day in Pretoria, with a zero outcome. Daily Maverick, 23 October 2015. http://www.dailymaverick.co.za/article/2015-10-23-feeshavefallen-a-big-day-inpretoria-with-a-zero-outcome/\#.V5M7kqIj4WA (http://www.iol.co.za/news/politics/0-increasemay-cost-state-r24-billion-1940592 (Accessed 23 July 2016).

Centre for Higher Education Transformation. 2015. New higher education performance indicator data 2009 to 2013. http://www.chet.org.za/data/sahe-open-data (Accessed 23 July 2016).

Department of Education. 2001. National plan for higher education. http://www.justice.gov.za/ commissions/FeesHET/docs/2001-NationalPlanForHigherEducation.pdf (Accessed 28 July 2016).

Department of Higher Education and Training. 2004. A new funding framework: How government grants are allocated to public higher education institutions. http://www.dhet.gov.za/ Reports\%20Doc\%20Library/New\%20Funding\%20Framework\%20How\%20Government\%20gr ants\%20are\%20allocated\%20to\%20Public\%20Higher\%20Education\%20Institutions.pdf (Accessed 28 July 2016).

Department of Higher Education and Training. 2013. White paper for post-school education and training. http://www.dhet.gov.za/SiteAssets/Latest\%20News/White\%20paper\%20for\%20postschool\%20education\%20and\%20training.pdf (Accessed 28 July 2016).

Department of Higher Education and Training. 2014. Ministerial statement on university funding: 2015/16 and 2016/17. http://www.dhet.gov.za/Financial\%20and\%20Physical\%20Planning/ Ministerial\%20Statement\%20at\%20University\%20funding;\%202015-16\%20and\%2020162017,\%20November\%202014.pdf (Accessed 28 July 2016).

Department of Higher Education and Training. 2015. Statistics on Post-School Education and Training in South Africa: 2013. March. http://www.dhet.gov.za/DHET\%20Statistics\%20Publication/ Statistics\%20on\%20Post-School\%20Education\%20and\%20Training\%20in\%20South\%20Africa \%202013.pdf (Accessed 27 June 2016).

Department of Higher Education and Training. 2016. University state budgets: Public report.

DHET see Department of Higher Education and Training.

Economic Development Department. 2011. The new growth path: Framework. Economic Development Department. http://www.economic.gov.za/communications/publications/new-growth-path-series (Accessed 28 July 2016).

Fataar, A. 2015. Why the fees must fall. Socialistworker.org October 27. https://socialistworker.org/ 2015/10/27/why-the-fees-must-fall (Accessed 23 July 2016).

Fin24. 2015. Student fees: Facts, figures and observations. October 22. http://www.fin24.com/ economy/student-fees-facts-figures-and-observations-20151022 (Accessed 23 July 2016).

Fourie, J. 2015. A blanket university fee reduction benefits the wealthy - and slows change. eNCA 
October 20. https://www.enca.com/opinion/blanket-university-fee-reduction-benefits-wealthy\%E2\%80\%93-and-slows-change (Accessed 23 May 2016).

Institute of Race Relations. 2016. Education 2016 SA survey. http://irr.org.za/reports-andpublications/south-africa-survey/south-africa-survey-2016 (Accessed 28 July 2016).

Jansen, J. 2015. UFS welcomes Pres. Jacob Zuma's statement about 0\% increase in tuition fees for 2016. University of the Free State. October 23. http://www.ufs.ac.za/templates/news-archiveitem?news=6536 (Accessed 23 July 2016).

Kritsonis, Alicia. 2005. Comparison of change theories. International Journal of Scholarly Academic Intellectual Diversity 8(1): 1-7.

Levasseur, Robert E. 2001. People skills: Change management tools: Lewin's change model. Interfaces 31(4): 71-73.

Makhanya, M. 2015. Statement from Prof Mandla Makhanya regarding the announcement of a 0\% increase in student fees for 2016. October 30. http://www.unisa.ac.za/news/ index.php/2015/10/statement-from-prof-mandla-makhanya-regarding-the-announcement-of-a-0increase-in-student-fees-for-2016/ (Accessed 23 July 2016).

National Planning Commission. 2011. National development plan 2030 - Executive summary. http://www.gov.za/sites/www.gov.za/files/Executive\%20Summary-NDP\%202030\%20\%20Our\%20future\%20-\%20make\%20it\%20work.pdf (Accessed 28 July 2016).

National Treasury. 2016. Estimates of national expenditure. http://www.treasury.gov.za/ documents/national\%20budget/2016/ene/FullENE.pdf (Accessed 28 July 2016).

News24Wire. 2015. What you need to know about university fees in South Africa. BusinessTech October 23. http://businesstech.co.za/news/general/102010/what-you-need-to-know-aboutuniversity-fees-in-south-africa/ (Accessed 201623 July).

News101. 2016. Estimated R460 million cost of damage during \#FeesMustFall protest. June 9. http://www.news101.co.za/2016/06/09/estimated-r460-million-cost-damage-feesmustfallprotest/ (Accessed 23 July 2016).

Omar, Y. 2016. Free education for the poor on the cards. January 21. http://www.uct.ac.za/ dailynews/?id=9537 (Accessed 18 March 2016).

Rensburg, I. 2016. Communiqué by Prof Ihron Rensburg to parents/guardiansofUJstudents. January 11. http://www.uj.ac.za/newandevents/Pages/Communiqu\%C3\%A9-by- Prof- Ihron- Rensburgto parents-guardians- of- UJ- Students.aspx ( Accessed 23 March 2016).

Schein, Edgar H. 1996. Kurt Lewin's change theory in the field and in the classroom: Notes toward a model of managed learning. Systems Practice 9(1): 27-47.

Statistics South Africa. 2015. Financial statistics of higher education institutions. http://www.statssa.gov.za/publications/P91031/P910312015.pdf (Accessed 21 November 2016).

Van Staden, L. 2015. TUT Vice-Chancellor speaks on \#FeesMustFall. October 23. http://www.tut.ac.za/ News/Pages/TUTVice-Chancellorspeaks onFeesMustFall.aspx (Accessed 18 March 2016).

Venter, R. 2015. \#FeesMustFall and the SA economy Newsclip. https://www.newsclip.co.za/Uploads/ Files/feesmustfall.pdf (accessed 9 June 2016).

Wangenge-Ouma, G. and N. Cloete. 2008. Financing higher education in South Africa: Public funding, non-government revenue and tuition fees. South African Journal of Higher Education 22(4): 14.

Wild, F. and A. Mbatha. 2015. Zuma says SA faces ‘serious struggle’ to meet goals. Fin24, October 28. http://www.fin24.com/Economy/Zuma-says-SA-faces-serious-struggle-to-meet-goals20151028 (Accessed 23 July 2016). 